\title{
A DOKTORI KÉPZÉSBŐL LEMORZSOLÓDÓK VIZSGÁLATA ${ }^{1}$
}

\author{
SZIGETI FRUZSINA \\ Debreceni Egyetem, Humán Tudományok Doktori Iskola, \\ Neveléstudományi Doktori Program
}

A magyar felsőoktatásból történő lemorzsolódási arány közel 40 százalék, ami képzési szintek szerint a tudományos képzésben a legmagasabb. Kutatásunkban megvizsgáltuk a 2010/2011-es és a 2014/2015-ös tanév őszi szemeszterében beiratkozott PhDhallgatók lemorzsolódásának mintázatait, és elemeztük azt is, hogy a felvett kreditek száma, a passzív státusz, a képzési terület, a képző intézmény és a képzés finanszírozási formája befolyásolja-e a lemorzsolódást. Elemzésünk alapját a Felsőoktatási Információs Rendszer (FIR) adatai adják. Eredményeink azt mutatják, hogy akárcsak a többi képzési területnél a PhD-képzés esetében is az 1. és a 2. szemeszter a legkritikusabb lemorzsolódási periódus.

Kulcsszavak: felsőoktatás, lemorzsolódás, PhD-képzés

The dropout rate is nearly $40 \%$ in the Hungarian higher education which is the highest in doctoral education according to the level of education. In our research, we investigated the patterns of dropout among $\mathrm{PhD}$ students enrolled in the autumn semesters of the school years 2010/2011 and 2014/2015. We also explored whether the number of enrolled credits, the passive status, the field of study, the training institution and funding influence the phenomenon of dropout. Our results come gained the Higher Educational Informational System show that PhD students should be taken into regard from the enrolment as the first and second semesters are the most critical periods regarding dropout like any other level of education.

Keywords: higher education, dropout, $\mathrm{PhD}$ education

Levelező szerző: Szigeti Fruzsina, abszolvált PhD-hallgató, Debreceni Egyetem, Humán Tudományok Doktori Iskola, Neveléstudományi Doktori Program, 4032 Debrecen, Egyetem tér 1.

E-mail: szigeti.fruzsina.89@gmail.com

1 A tanulmány az 123847 számú projekt keretében készült, ami a Nemzeti Kutatási Fejlesztési és Innovációs Alapból biztosított támogatással, a K-17 pályázati program finanszírozásában valósult meg. 


\section{Bevezetés}

$\mathrm{T}$ anulmányunk a doktoranduszok lemorzsolódásának mintázatait elemzi a Felsőoktatási Információs Rendszerből (FIR) nyert adatok alapján. A vizsgálat hiánypótló munkának bizonyul, ugyanis a nemzetközi felsőoktatás-kutatásokban a PhD-hallgatókról kevés adat áll rendelkezésre (Papp Z.-Csata 2014), lemorzsolódásuk makroszintü összefüggésrendszerét rendszerint nem ismertetik.

$\mathrm{Az}$ OECD-országok trendjeihez képest Magyarországon alacsony a felsőoktatásban első végzettségüket szerzők aránya, különösen doktori szinten (OECD 2015), noha az elmúlt két és fél évtizedben hazánkban is megnövekedett a felsőfokú végzettségűek abszolút száma és aránya (Kurátb-Héráné Tótb-Sipos 2014). Az 1993-as magyar felsőoktatási törvény által bevezetett $\mathrm{PhD}$-képzés mint egyetlen tudományos fokozatot biztosító képzés (Veroszta 2010) fellendülése szintén a 2000-es évek elejére tehető, hozzátéve, hogy 2005-től a PhD-hallgatók száma nem kezdett oly drasztikus módon csökkeni, mint ami a felsőoktatás egészében tapasztalható. Mindezek ellenére az Európai Bizottság (2015) jelentése megállapítja, hogy ezer 25 és 34 év közötti magyar lakosra mindössze 0,8 PhD-fokozattal rendelkező jut, miközben az európai uniós átlag 1,69. A magyar adat nem csupán a fejlett országokkal összehasonlítva alacsony (Németország: 2,65, Svédország: 2,9, Svájc: 3,68), hanem az olyan szomszédos országokkal, közvetlen nemzetközi versenytársakkal szemben is, mint Románia (1,4), Csehország (1,3), illetve Szlovákia $(3,1)$ (Emberi Eröforrások Minisztériuma é. n.).

Mindezek kapcsán alapvető kérdésként merül fel, hogy: Mi lehet a lemaradás hátterében? Miért alacsony a magyar egyetemek által kiadott PhD-fokozatok száma és aránya? Mennyire játszik szerepet ebben a lemorzsolódás, s a PhD-hallgatók lemorzsolódásának milyen prediktorai vannak? A kérdések megválaszolásához kvantitatív kutatási módszereket alkalmaztunk. Kutatásunk alapját a Felsőoktatási Információs Rendszer (FIR) biztosította.

\section{Elméleti háttér}

A felsőoktatásból való lemorzsolódás az 1960-as években került a vizsgálatok középpontjába, majd Tinto interakcionista modellje révén az 1970-es években teoretikus formában is megjelent (Bocsi et al. 2018, 2019; Szigeti et al. 2018). Azóta számos modell - lásd például Astin 1993; Bean 1985, 2005; OECD 2012 - került kidolgozásra, amelyek a lemorzsolódás hátterében különböző kiváltó okokat sejtenek és feltételeznek. Ilyenek például az egyén pszichológiai jellemzői, a hallgató magatartása, a családi háttér, a szociológiai, társas aspektusok, a pedagógiai-pszichológiai faktorok, az intézményi struktúra, vagy az intézményi erőforrások (Bocsi et al. 2018, 2019). Napjaink felsőoktatás-kutatásaiban a felsorolt tényezők vizsgálatára úgy tekintenek a kutatók, mint a felsőoktatási rendszerben való megrekedés, a lassúbb tanulmányi elöremenetel és a lemorzsolódás előrejelzőire. Hozzátéve, hogy ezen tényezőket az esetek túlnyomó többségében, a hozzávetőleg 36-38 százalékos lemorzsolódási rátával jellemezhető képzési területen, az alapképzésen (BA/BSc) vizsgálják (Bocsi et al. 2018, 2019; Fenyves et al. 2017; Merill 2015; Müller-Schneider 2013; Pusztai 2017; Pusztai-Szigeti 2018; Szemerszki-Pusztai 2017; Szigeti et al. 2018; Vossensteyn-Stensaker-Kottmann 2015). 
Ennél jóval magasabb lemorzsolódási arányszámot tudhat magáénak a doktori képzés (Bocsi et al. 2018, 2019; Derényi 2015; Emberi Erőforrások Minisztériuma 2016; Fenyves et al. 2017; Mihály 2013), amiről azonban csak ritkán ejtenek szót a kutatók, s a hátterében meghúzódó okokat még kevésbé vagy egyáltalán nem azonosítják.

Magyarországon 2008 óta a $\mathrm{PhD}$-fokozatot szerzettek száma mintegy 1200 fó, arányuk a képzési időnek megfelelő évfolyam létszámarányában kb. 43-50\% (Emberi Eröforrások Minisztériuma 2016; Mihály 2013). Mihály (2013) eredményei szerint a doktori képzésbe felvételt nyert hallgatók 20 százaléka már a tanulmányi időn belül abbahagyja a képzést, nem abszolvál, abszolutóriumot csupán 60 százalék szerez. A doktori képzésből való magas lemorzsolódási arány hátterében egyrészt az állhat, hogy nem mindig a legtehetségesebbek, a legelhivatottabbak és a legelkötelezettebbek kerülnek be a doktori képzésbe. A tehetséges és a jó vagy kiváló minősítéssel rendelkező osztatlan- és mesterdiplomások jelentős része már a végzés után elhelyezkedik a köz-vagy magánszektorban, vagyis megtörténhet, hogy a munkaerőpiacra be nem jutottak, a doktori képzést egyfajta parkoló pályának tekintők nagy arányban kerülnek be a képzésbe, s közülük sokan végül nem szereznek tudományos fokozatot. További ok lehet, hogy a piacképes területen tevékenykedő doktoranduszokat még a képzés befejezése, az abszolutórium megszerzése előtt elcsábítja a magasabb fizetési lehetőségekkel gyorsabb előremenetelt biztosító magánszektor. A PhD-lemorzsolódás hátterében állhat a képzési és kimeneteli követelmények nem teljesítése, az abszolutórium meg nem szerzése is, valamint nagy gondot és kihívást jelenthet az értekezés megírása is, amire az abszolutórium megszerzését követően, gyakran munka mellett kell sort keríteni. Mindezeken túl a $\mathrm{PhD}$-program elhagyásában szintén szerepet játszhatnak a pénzügyi nehézségek, a családi kötelezettségek, valamint a külső támogatás (házastárs, munkáltató, témavezető, doktori iskolavezető) hiánya (AmpawJaeger 2012; Fináncz 2008, 2010; Litalien-Guay 2015; Pusztai 2009; Sadlak 2004).

\section{A kutatás kérdései, hipotézisei}

Tanulmányunk elsődleges célja a PhD-hallgatók lemorzsolódási mintázatainak azonosítása. Ennek megfelelően arra a kérdésre keressük a választ, hogy milyen mintázatot ír le a doktoranduszok lemorzsolódása, a kreditszerzés, a passziválás, a képző intézmény és a képzési terület milyen hatással van a képzés sikertelen befejezésére. Azt feltételezzük, hogy a szelektív, doktori képzést biztosító intézményekbe felvételt nyert hallgatók csaknem egyötöde már a képzési időn belül feladja a képzést (Fináncz 2008; Mihály 2013), amiben szerepet játszik a szigorú követelményrendszer, az elöírt kreditszám el nem érése, a (gyakorta igénybe vett) passzív szemeszterek száma, valamint a költségtérítéses finanszírozási forma. Ezenfelül feltételezzük a doktoranduszok tudományos kapcsolathálókba való beágyazottságának tudományterületi eltéréseit is, úgy véljük, hogy a természet-, az orvos- és az agrártudományok esetében a legalacsonyabb a lemorzsolódási arányszám, míg a művészetek, a humán- és a társadalomtudományoknál a legalacsonyabb (Elgar 2003; Fináncz 2008; Györffy 2015; Mihály 2013; Nettles-Millett 2006).

Elemzésünk során olyan eredményeket ismertetünk, amelyek a Felsőoktatási Információs Rendszerből származnak, s melyek kizárólag a 2010/2011-es és a 2014/2015-ös 
tanév őszi szemeszterében beiratkozott PhD-hallgatókra vonatkoznak. ${ }^{2}$ Lemorzsolódott $\mathrm{PhD}$-hallgatóknak azokat tekintjük, akik a FIR adatbázis alapján lemorzsolódottak, vagyis nem fejezték be a hároméves képzést, nem szereztek abszolutóriumot.

\section{A kutatás eredményei}

A doktori képzésbe beiratkozók között 2010-ben a férfiak, 2014-ben viszont a nők voltak némiképp nagyobb arányban ( nő $_{2010^{*}} 48 \%$, férfi $_{2010^{*}}: 52 \%$ ) (nő ${ }_{2014}: 51,9 \%$, férf ${ }_{2014^{*}}$ $48,1 \%)$. Ez a tendencia azért is figyelemre méltó, mivel jelenleg kevesebb nő rendelkezik PhD-fokozattal, mint férfi (Freeman 2004; Fényes 2010; Szigeti 2016). Finanszírozási forma szerint 2014-ben nagyobb arányban (51,4\%) kezdték meg képzésüket állami támogatással, mint 2010-ben (40,3\%), köszönhetően a finanszírozott keretszámok emelésének. Képzési területeket tekintve jelentősebb változások nem mentek végbe, továbbra is a bölcsészetet (2010:21,2\%, 2014:21,8\%) és a társadalomtudományt (2010: 20,7\%, 2014: 23,3\%) választották a legnagyobb arányban, míg az agrár- (2010:6,5\%, 2014: $5,2 \%)$, a müszaki- (2010: 12,3\%, 2014: 11\%) és a hittudományt (2010: 1,8\%, 2014: 1,2\%) a legkevesebben. Ez az eredmény önmagában nem meglepő, hisz tudjuk, képzési szinttől függetlenül ez utóbbi három tudományterületen igen magas a lemorzsolódás (Bocsi et al. 2018, 2019; Fenyves et al. 2017), ugyanakkor valószínüsíthető, hogy ezeken a képzéseken ténylegesen a legrátermettebbek maradnak bent és szereznek fokozatot.

Kutatásunk fő célja a doktoranduszok lemorzsolódásmintázatainak feltérképezése, ezért választ kell keresnünk arra, hogy a beiratkozott $\mathrm{PhD}$-hallgatók hány százaléka nem jutott el a képzés végéig. Elemzési keretünk értelmében minden 2010-ben és 2014ben doktori tanulmányt kezdőnek, a passzív félév(ek) igénybevétele nélkül, meg kellett szereznie az abszolutóriumot a FIR adatbázis befagyasztásának időpontjáig, vagyis a 2016/2017-es tanév tavaszi félévéig. 2010-ben magasabb volt az abszolutóriummal rendelkezők aránya (70,5\%), mint 2014-ben (50,3\%), azonban észrevehető, hogy ez utóbbi

1. táblázat: A PhD-képzésekre beiratkozottak alapmegoszlásai 2010 és 2014

\begin{tabular}{|c|c|c|c|c|}
\hline & \multicolumn{2}{|c|}{ 2010.év } & \multicolumn{2}{|c|}{ 2014. év } \\
\hline & Elemszám & $\%$ & Elemszám & $\%$ \\
\hline Végzett (abszolutóriummal vagy oklevéllel) & 1631 & 70,5 & 1094 & 50,3 \\
\hline Átvétel, képzésváltás & 8 & 0,3 & 17 & 0,8 \\
\hline Lemorzsolódott & 503 & 21,7 & 303 & 13,9 \\
\hline Egyéb kilépés & 4 & 0,2 & 2 & 0,1 \\
\hline Még tanul & 167 & 7,2 & 761 & 35,0 \\
\hline Összesen & 2313 & 100,0 & 2177 & 100,0 \\
\hline
\end{tabular}

Forrás: FIR adatbázis, Oktatási Hivatal

2 A vizsgálatban szereplőknél az előírt kreditmennyiség minimum 180, a képzési idő hat szemeszter. (A 2010-ben és 2014-ben a legmagasabb szintű posztgraduális képzést kezdőkre még nem volt érvényes a nemzeti felsőoktatásról szóló 2011. évi CCIV. törvény módosítása, miszerint a doktori képzésben legalább 240 kreditet kell szerezni, a képzési idő nyolc félév.) 
bázisévben magas volt azoknak az aránya is, akik még bent voltak a képzésben (35\%), vagyis még nem morzsolódtak le. Feltehető, ők voltak azok, akik éltek a jogszabály szerint biztosított passziválási lehetőséggel. A hároméves képzési időn belül ténylegesen lemorzsolódottak aránya 2010-ben 21,7\%, míg 2014-ben 13,9\% volt, vagyis a két vizsgált év együttes vizsgálata alapján összességében megállapítható, hogy a beiratkozott $\mathrm{PhD}$ hallgatók mintegy 18-19 százaléka nem teljesítette a képzési és kimeneteli követelményeket, nem jutott el az abszolutórium megszerzéséig (1. táblázat), amely egybevág Fináncz (2008) és Mihály (2013) azon megállapításával, hogy a doktori iskolákba felvételt nyert hallgatók körülbelül egyötöde már a képzési időn belül megszakítja a tanulmányait.

2. táblázat: A lemorzsolódók által igénybe vett aktív félévek száma

\begin{tabular}{|c|c|c|c|c|}
\hline & & & \multicolumn{2}{|c|}{ Lemorzsolódók } \\
\hline & & & 2010 & 2014 \\
\hline \multirow{24}{*}{ 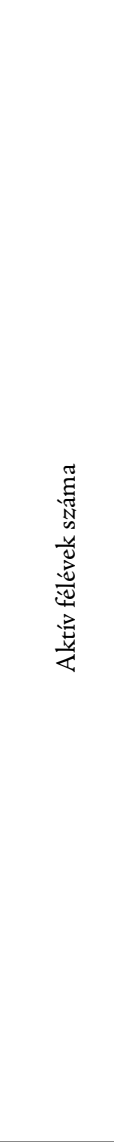 } & \multirow{2}{*}{1} & $N$ & 101 & 93 \\
\hline & & $\%$ & $20,1 \%$ & $30,7 \%$ \\
\hline & \multirow{2}{*}{2} & $N$ & 116 & 87 \\
\hline & & $\%$ & $23,1 \%$ & $28,7 \%$ \\
\hline & \multirow{2}{*}{3} & $N$ & 49 & 48 \\
\hline & & $\%$ & $9,7 \%$ & $15,8 \%$ \\
\hline & \multirow{2}{*}{4} & $N$ & 80 & 40 \\
\hline & & $\%$ & $15,9 \%$ & $13,2 \%$ \\
\hline & \multirow{2}{*}{5} & $N$ & 44 & 6 \\
\hline & & $\%$ & $8,7 \%$ & $2,0 \%$ \\
\hline & \multirow{2}{*}{6} & $N$ & 90 & 29 \\
\hline & & $\%$ & $17,9 \%$ & $9,6 \%$ \\
\hline & \multirow{2}{*}{7} & $N$ & 9 & - \\
\hline & & $\%$ & $1,8 \%$ & - \\
\hline & \multirow{2}{*}{8} & $N$ & 7 & - \\
\hline & & $\%$ & $1,4 \%$ & - \\
\hline & \multirow{2}{*}{9} & $N$ & 5 & - \\
\hline & & $\%$ & $1,0 \%$ & - \\
\hline & \multirow{2}{*}{10} & $N$ & 1 & - \\
\hline & & $\%$ & $0,2 \%$ & - \\
\hline & \multirow{2}{*}{11} & $N$ & 0 & - \\
\hline & & $\%$ & $0,0 \%$ & - \\
\hline & \multirow{2}{*}{12} & $N$ & 1 & - \\
\hline & & $\%$ & $0,2 \%$ & - \\
\hline Összesen & & $N$ & 503 & 303 \\
\hline$\%$ & & $100,0 \%$ & $100,0 \%$ & \\
\hline
\end{tabular}

Forrás: FIR adatbázis, Oktatási Hivatal 
Ez a fajta lemorzsolódás már a képzési idő elején jelentkezett, akárcsak a többi képzési szintnél (Bocsi et al. 2018, 2019). A 2010-ben lemorzsolódók több mint 43 százaléka, a 2014-ben lemorzsolódók mintegy 60 százaléka egy vagy kettő aktív szemeszter után a képzés elhagyása mellett döntött (2. táblázat).

A lemorzsolódás hátterében különböző okok húzódhatnak meg, mely okok a FIR-ben rögzítettek szerint az alábbiak lehetnek: bejelentkezés elmulasztása, fizetési hátralék a képzésben, saját bejelentés a képzés megszakítására, képzési kötelezettségek nem teljesítése, egészségügyileg alkalmatlanná válás a képzésre, kizárás fegyelmi határozat alapján stb.

A vizsgált években a legmagasabb arányban saját bejelentés alapján szakították meg képzésüket a hallgatók. Sajnos a saját bejelentés hátterében meghúzódó okokat nem tudjuk azonosítani. Ha nem volt elég pénze a hallgatónak a költségtérítés befizetésre, akkor is jelölhették a „saját bejelentést", illetve abban az esetben is, ha a hallgató kiábrándult, csalódott a képzésben. A 2010-ben lemorzsolódók 47,3 százaléka, a 2014-ben lemorzsolódók 61,7 százaléka saját bejelentés alapján szakította meg a $\mathrm{PhD}$-képzést. Emellett jelentős szerepet játszott a képzési kötelezettségek nem teljesítése (2010 : 31,2\%, 2014: 17,8\%), valamint a bejelentkezés elmulasztása az elöírtnál többször, vagyis a jogszabály által megengedettnél többszöri passziválás is (2010:20,3\%, 2014:19,1\%).

A PhD-hallgatók lemorzsolódásában közrejátszó képzési kötelezettségek nem teljesítését a kreditszerzéssel tudtuk vizsgálni. Köztudott, 2016 szeptemberéig a doktori képzés elvégzéséhez legfeljebb 180 kredit megszerzése volt szükséges, félévente 28-30 kreditet kellett gyưjteni. Ehhez képest a lemorzsolódók átlagosan 40-50 kreditet gyüjtöttek össze, rendszerint a 3. szemeszterük végéig, míg a lemorzsolódásban nem érintett doktoranduszok ezt a kreditmennyiséget már a 2. szemeszterükben elérték.

A passziválás is fontos előrejelzője a lemorzsolódásnak. A Khí-négyzet próba eredményeinek értelmében a lemorzsolódók és a lemorzsolódásban nem érintettek között szignifikáns eltérés volt a passzív státusz igénybevétele szempontjából $\left(p_{2010}=0,000\right.$, $\left.p_{2014}=0,000\right)$. A 2010-ben lemorzsolódók 72 százalékának, a 2014-ben lemorzsolódók 58,7 százalékának volt passzív státusza legalább egy szemeszteren keresztül, míg a 2010 ben lemorzsolódásban nem érintettek csupán 26,1 százaléka, a 2014-ben lemorzsolódásban nem érintettek 23,3 százaléka passzivált. A varianciaanalízis eredményei szerint az igénybe vett passzív félévek száma között is jelentős különbség mutatkozott a két csoport között $\left(p_{2010}=0,000, p_{2014}=0,000\right)$. A lemorzsolódók átlagosan három alkalommal vették igénybe a passzív státuszt, a nem lemorzsolódók egyszer. Természetes módon a lemorzsolódók között a passziválás az önköltséges hallgatókra jellemzőbb volt (2010: 73\%, 2014: 63,2\%), mint az ösztöndíjasok esetében (2010:66,6\%, 2014: 49,5\%), azonban e két csoport közötti eltérés nem volt szignifikáns $\left(p_{2010}=0,308, p_{2014}=0,080\right)$. Amennyiben az igénybevett passzív félévek számát vizsgáljuk, már jelentős különbség mutatkozik a finanszírozási formák között: a költségtérítéses hallgatók bátrabban és gyakrabban passziváltatták magukat az ösztöndíjasokhoz képest $\left(p_{2010}=0,029, p_{2014}=\right.$ 0,044). Ennek az lehet a magyarázata, hogy az ösztöndíjas PhD-hallgatóknak a legfőbb havi jövedelmi forrásuk az aktív hallgatói jogviszonyból származik, ami a tanórákon való részvételekből, a kutatási tevékenységekből, a tudományos konferenciákon való megjelenésekből, az óratartási kötelezettségekből stb. tevődik össze, s akik számára bizonytalanabb és kiszámíthatatlanabb a passzív státusz igénybevétele, mint azoknak, akik eleve munkaerőpiaci pozícióban vannak, s költségtérítésesek a tudományos kép- 
zésben. Feltehetőleg az állami ösztöndíjban részesülő doktoranduszok kizárólag akkor kezdeményezik a passzív státuszt, amikor konkrét munkaerőpiaci megkeresést kapnak, s a munkaerőpiaci pozícióval magasabb jövedelmi szintet érnek el, mint az ösztöndíjjal.

A PhD-hallgatók lemorzsolódása szempontjából meghatározó a képzés területe is. A különböző képzési területeken jelentősen eltér a lemorzsolódó hallgatók aránya (Khínégyzet próba: $\left.p_{2010}=0,000, p_{2014}=0,005\right)$. A lemorzsolódottak között a legnagyobb arányban a társadalom- és a bölcsészettudomány $\mathrm{PhD}$-hallgatói szerepeltek, míg a legkisebb ráta a művészet és a hittudomány területén koncentrálódott. A lemorzsolódottak között átlagosan 31 százalékban a társadalomtudósok, 19,5 százalékban a bölcsészek szerepeltek. A férfiak egyértelmüen a társadalomtudományról morzsolódtak le a legnagyobb arányban, míg a nők a bölcsészettudományról. A művészet $(1,9 \%)$ és a hittudomány $(1,5 \%)$ tudományterületek esetében lényegesen alacsonyabb a lemorzsolódás valószínüsége, kiemelve, hogy ezeken a tudományterületeken eleve jóval kisebb a $\mathrm{PhD}$-hallgatók száma is.

Érdekes kérdést vet fel, hogy milyen mintázatot ír le képző intézmények szerint a PhD-hallgatók lemorzsolódása. A magyarországi intézmények közül Hrubos (2012) munkája alapján a klasszikus négy állami egyetemet, a Debreceni Egyetemet (DE), az Eötvös Loránd Tudományegyetemet (ELTE), a Pécsi Tudományegyetemet (PTE), valamint a Szegedi Tudományegyetemet (SZTE) vontuk a vizsgálatba. Mindkét bázisévben a Khí-négyzet próba szerint szignifikáns eltérés mutatkozott a felsőoktatási intézmények lemorzsolódási arányai között $\left(p_{2010}=0,000, p_{2014}=0,005\right)$. A legmagasabb arányban a PTE doktori képzéseiről morzsolódtak le, átlagosan az itt tanuló PhD-hallgatók 32,9 százaléka hagyta abba a képzést az abszolutórium megszerzése nélkül. Magas, 29 százalékos lemorzsolódási arány tapasztalható az ELTE esetében is, míg az SZTE-n 24 százalék a PhD-képzésekről lemorzsolódók aránya. A vizsgált években a $\mathrm{DE}$ rendelkezett a legkedvezőbb rátával, hiszen a beiratkozók 14 százaléka morzsolódott le a hároméves képzés során, vagyis 86 százalék eljutott a képzés végéig. Képzési területek szerint, minden egyes képzési terület lemorzsolódási arányszáma a DE-n volt a legkedvezőbb, míg a PTE-n a legkedvezőtlenebb.

\section{Összegzés}

Vizsgálatunkban a PhD-hallgatók lemorzsolódásmintázatainak feltérképezésére vállalkoztunk makroszintü megközelítésből, amiben az adminisztratív célú adatgyüjtésen alapuló Felsőoktatási Információs Rendszer volt segítségünkre. Az elemzett adatbázisban a 2010/2011-es és a 2014/2015-ös tanév első félévre beiratkozott PhD-hallgatók szerepeltek.

A doktoranduszok lemorzsolódásának elemzésekor megvizsgáltuk, hogy a beiratkozott PhD-hallgatók hány százaléka nem szerzett abszolutóriumot, azaz hány százalékuk morzsolódott le. A tudományos ismeretek elmélyítésére szolgáló posztgraduális képzés kimeneteli követelményeit a vizsgált két tanévben a PhD-hallgatók átlagosan mintegy ötöde nem teljesítette. A doktori iskolákba felvételt nyert és lemorzsolódott hallgatók több mint 50 százaléka már az első vagy a második szemeszterben megszakította a képzést. A PhD-hallgatók lemorzsolódásának rizikófaktorai között szerepelt a passzív jogviszony igénybevétele, a passzív félévek száma, a képzés területe és a finanszírozási forma. 
Összességében a kutatás makroszintű eredményei kellően bizonyítják, hogy a PhDhallgatók lemorzsolódásának és a lemorzsolódás okainak megismerése, azonosítása elengedhetetlenül fontos, amihez számos mikroszinten elvégzett vizsgálatra is szükség van.

\section{IRODALOM}

Ampaw, F. D. \&. Jaeger, A. J. (2012) Completing the Three Stages of Doctoral Education: An Event History Analysis. Research in Higher Education, Vol. 53. No. 6. pp. 640-660.

Astin, A. (1993) What Matters in College? Four Critical Years Revisited. San Francisco, Jossey-Bass.

Bean, J. P. (1985) Interaction Effects Based on Class Level in an Exploratory Model of College Student Dropout Syndrome. American Educational Research Journal, Vol. 22. No. 1. pp. 35-64.

Bean, J. P. (2005) Nine Themes of College Student Retention. In: A. Seidman (ed.) College Student Retention: Formula for Student Succes. Westpont, Praeger Publishers. pp. 215245.

Bocsi V., Ceglédi T., Kocsis Zs., Kovács K. E., Kovács K., Müller A., Pallay K., Szabó B. É., Szigeti F. \& Tóth D. A. (2018) A pedagógus hallgatók késleltetett diplomaszerzése interjúk alapján. In: Pusztai G. \& Szigeti F. (eds) Lemorzsolódás és perzisztencia a felsőoktatásban. Debrecen, Debreceni Egyetemi Kiadó, Debrecen University Press. pp. 63-90.

Bocsi V., Ceglédi T., Kocsis Zs., Kovács K. E., Kovács K., Müller A., Pallay K., Szabó B. É., Szigeti F. \& Tóth D. A. (2019) The Discovery of the Possible Reasons for Delayed Graduation and Dropout in the Light of a Qualitative Research Study. Journal of Adult Learning Knowledge and Innovation, Vol. 3. No. 1. pp. 27-38.

DeréNyi A. (2015) Bizonyítékokra alapozott kormányzás és a kommunikáció képzés. Jelkép, 2015/1KLSZ. pp. 1-21. https://communicatio.hu/jelkep/2015/kulonszam/ JelKep_2015_kulonszam_Derenyi_Andras.pdf [Letöltve: 2019. 12.14.]

Elgar, F. J. (2003) PhD Degree Completion in Canadian Universities. Halifax (NS), Dalhousie University.

Emberi Erőforrások Minisztériuma (é.n.) Fokozatváltás a felsőoktatásban. A teljesitményelvü felsőoktatás fejlesztésének irányvonalai.

http://www.kormany.hu/download/d/90/30000/fels\%C5\%91oktat\%C3\%A1si\%20 koncepci\%C3\%B3.pdf [Letöltve: 2019. 11. 14.]

Emberi Erőforrások Minisztériuma (2016) Fokozatváltás a felsőoktatásban középtávú szakpolitikai stratégia. Cselekvési terv 2016-2020.

http://www.kormany.hu/download/b/fa/11000/EMMI\%20

fokozatv\%C3\%A1lt\%C3\%A1s\%20fels\%C5\%91oktat\%C3\%A1s\%20

cselekv\%C3\%A9si\%20terv\%20Sajt\%C3\%B3\%20\%C3\%A9s\%20

Kommunik\%C3\%A1ci\%C3\%B3s\%20F\%C5\%91oszt\%C3\%A1ly\%2020170627.pdf [Letöltve: 2019.11.21.]

FÉnyes H. (2010) A nemi sajátosságok különbségének vizsgálata az oktatásban. A nök hátrányainak felszámolódása? Habilitációs értekezés. Debrecen, Debreceni Egyetem.

Fenyves V., Bácsné Bába É., Szabóné Szőke R., Kocsis I., Juhász Cs., Máté E. \& Pusztai G. (2017) Kísérlet a lemorzsolódás mértékének és okainak megragadására a 
Debreceni Egyetem Gazdaságtudományi Kar példáján. Neveléstudomány. Oktatás Kutatás - Innováció, Vol. 5. No. 3. pp. 5-14.

FinánCz J. (2008) Tudományos utánpótlásképzés Európában és Magyarországon: A doktori képzésben résztvevők helyzete. $\mathrm{PhD}$-értekezés. Debrecen, Debreceni Egyetem.

FinÁNCZ J. (2010) Kettő az egyben: oktató és hallgató. Avagy a doktoranduszlét viszontagságai a debreceni doktoranduszok szemszögéből. In: JuHÁsz E. (ed.) Harmadfokú képzés, felnöttképzés és regionalizmus. Debrecen, Center for Higher Education Research and Development. pp. 222-229.

Freeman, C. E. (2004) Trends in Educational Equity of Girls and Woman: 2004. National Center for Education Statistics U.S. Department of Education.

GYörfFy D. (2015) A közgazdaság-tudományi doktori iskolák helyzete Magyarországon. Közgazdasági Szemle, Vol. 57. No. 7-8. pp. 853-859.

Hrubos I. (2012, ed.) Elefántcsonttoronyból világitótorony. A felsőoktatási intézmények misszióinak bövülése, átalakulása. Budapest, Aula Kiadó.

Kuráth G., Héráné Tóth A. \& Sipos N. (2014, eds) PTE Diplomás Pályakövetö Rendszer. Tanulmánykötet 2014. Pécs, Pécsi Tudományegyetem.

Litalien, D. \& Guay, F. (2015) Dropout Intentions in Phd Studies: A Comprehensive Model Based on Interpersonal Relationships and Motivational Resources. Contemporary Educational Psychology, Vol. 41. No. 2. pp. 218-231.

Merill, B. (2015) Determined to Stay or Determined to Leave? Journal Studies in Higher Education, Vol. 40. No. 10. pp. 1859-1871.

Mihály Gy. (2013) PhD fokozatok nyomában. https://doktori.hu/index. php? menuid=351\&cid=236 [Letöltve: 2019.10 .21 .]

Müller, S. \& Schneider, T. (2013) Educational Pathways and Dropout From Higher Education in Germany. Longitudinal and Life Course Studies, Vol. 4. No. 3. pp. 218-241.

Netties, M. T. \& Millett, C. M. (2006) Three Magic Letters: Getting to PbD. Baltimore (MD), Johns Hopkins University Press.

OECD (2012) Equity and Qualityin Education: Supporting Disadvantaged Students and Schools. http://dx.doi.org/10.1787/9789264130852 [Letöltve: 2019. 12. 01.]

OECD (2015) Education at a Glance 2015-Hungary. https://www.oecd.org/hungary/ Education-at-a-glance-2015-Hungary-in-Hungarian.pdf [Letöltve: 2019. 11. 21.]

Papp Z. A. \& Csata Zs. (2014) Hungarian PhD Students Abroad: International Contexts and Specificities of the Carpathian Basin. Minorities Research, Vol. 16. No. 17. pp. 100131.

Pusztai G. (2009) Mentor vagy idol? A doktorandusz-témavezető kapcsolat formái a tudományos utánpótlásképzésben. In: Pusztai G. \& Rébay M. (eds) Kié az oktatáskutatás? Tanulmányok Kozma Tamás 70. születésnapjára. Debrecen, Csokonai Kiadó. pp. 337-353.

Pusztai G. (2017) Lemorzsolódási kockázatok és kompenzáló tényezők a felsőoktatásban. In: Kerülö J., Jenei T. \& Gyarmati I. (eds) XVII. Országos Neveléstudományi Konferencia: Program és absztrakt kötet. Nyíregyháza, Nyíregyházi Egyetem. pp. 250-255.

Pusztai G. \& Szigeti F. (2018, eds) Lemorzsolódás és perzisztencia a felsőoktatásban. Debrecen, Debreceni Egyetemi Kiadó, Debrecen University Press.

Pusztai G. \& Szemerszki M. (2017) A felsőoktatási lemorzsolódás mutatói és előrejelzői egy regionális egyetemen. In: BudA A. \& KISs E. (eds) Interdiszciplináris pedagógia és a taneszközök változó regiszterei. Tartalmi összefoglalók. Debrecen, Kapitális Kft. p. 61. 
Sadlak, J. (2004) Doctoral Studies and Qualifications in Europe and the United States: Status and Prospects. Bukarest, UNESCO. http://unesdoc.unesco.org/ images/0013/001364/136456e .pdf [Letöltve: 2019. 11. 21.]

Szigeti F. (2016) Nyíregyházán tanuló fiatalok továbbtanulási aspirációja. Educatio, Vol. 25. No. 4. pp. 629-636.

Szigeti F., Bocsi V., Ceglédi T., Kocsis Zs., Kovács-Nagy K., Müller A., Pallay K., Szaвó B. \& Tótн D. (2018) A pedagógus hallgatók késleltetett diplomaszerzésének és a lemorzsolódás lehetséges okainak feltárása egy kvalitativ kutatás tükrében. Budapest, Magyar Nevelés- és Oktatáskutatók Egyesülete. p. 197.

Veroszta Zs. (2010) Felsőoktatási értékek-hallgatói szemmel. A felsőoktatás küldetésére vonatkozó hallgatói értékstruktúrák feltárása. PhD-értekezés. Budapest, Budapesti Corvinus Egyetem.

Vossensteyn, H., Kottman, A., Jongbloed, B., Kaiser, F., Cremonini, L., Stensaker, B., Hovdhaugen, E. \& Wollscheid, S. (2015) Dropout and Completion in Higher Education in Europe. Luxembourg, Publications Office of the European Union.

A cikk a Creative Commons Attribution 4.0 International License (https://creativecommons.org/licenses/ by/4.0/) feltételei szerint publikált Open Access közlemény, melynek szellemében a cikk bármilyen médiumban szabadon felhasználható, megosztható és újraközölhető, feltéve, hogy az eredeti szerző és a közlés helye, illetve a CC License linkje és az esetlegesen végrehajtott módosítások feltüntetésre kerülnek. (SID_1) 